\title{
TOURISM MARKET, DISABILITY AND INEQUALITY: PROBLEMS AND SOLUTIONS
}

\author{
[Trh cestovního ruchu, handicap a nerovnost: problémy a řešení]
}

\author{
Marcin Popiel ${ }^{1}$ \\ ${ }^{1}$ Jagiellonian University in Krakow, Institute of Geography and Spatial Management, Gronostajowa Street 7 , \\ 30-387 Krakow, Poland \\ Email:marcin.popiel@uj.edu.pl
}

\begin{abstract}
Tourism for the disabled is starting to develop rapidly and currently it does not only constitute an attractive form of spending free time, however, it is mainly a form of rehabilitation or social activation. Disabled people have the right and they are willing to undertake the act of travelling like the rest of society. This particular group of people may be more prone to social exclusion and inequality and their rights and voices are often less heard in the mainstream of tourism industry. The aim of this paper is to present the situation of people with disabilities, who are often socially disadvantaged and discriminated. The article presents the results obtained from the survey and a review of statistical data and literature.
\end{abstract}

Keywords: accessibility, accessible tourism, inequality, market segmentation, people with disability, tourism.

JEL classification: L83

Doručeno redakci: 4.5.2016; Recenzováno: 16.5.2016; 15.6.2016; Schváleno k publikování: 19.10.2016

\section{Introduction}

Most of people with disabilities in their lives have encountered discrimination, rejection or exclusion. In the case of people with disabilities discrimination takes different forms depending on the type or degree of possessed limitations. This fact often becomes the cause of the withdrawal of such people from social life and scarifying their pleasures, even those connected with tourism and recreation.

Inequality in tourism for the disabled in social aspect is manifested in the encountered barriers (architectural, communicational, etc.), which much more affects the people with disabilities rather than the healthy ones - thus they are more discriminated. The study conducted for the purpose of this article shows that people with reduced mobility travel on average $60 \%$ less than healthy people, mostly due to the barriers. However, there is also a difference in the economic sphere. Products and tourism services, which are tailored to the needs of people with disabilities, are generally more expensive than those that a healthy person can benefit from. It is unfair, because people with disabilities are also discriminated in the labour market, hence they do not have jobs - especially women, who are discriminated not only by disability but also by gender - and they do not possess the same resources of money to finance an expensive holiday.

The aim of this paper is to present the situation of people with disabilities, who are often socially disadvantaged and discriminated. The article presents the results obtained from the survey and a review of statistical data and literature. 


\section{Situation of people with disability in tourism}

According to the definition stated in the Disability Discrimination Act 1995 'a disabled person' is someone who "has a physical or mental impairment which has a substantial and long - term adverse effect on his/her ability to carry out normal day - to - day activities". "Disability means that the person may have physical, cognitive/mental, sensory, emotional, developmental impairment or some combination of these. In the tourism area, this group of people is always assumed to be not interested in traveling. Tourism is one activity that many PwD (people with disability) feel must be sacrificed when in fact they hold the same tourism desires and needs as other social groups" (Ieng Loi, Hang Kong 2015). Disabled tourists want to visit even more destinations whenever possible before their physical condition deteriorates (Crompton 1979).

Since this group of people may be more prone to social exclusion and inequality, their rights and voices are often less heard in many mainstream tourism studies. Fortunately, with the constant call for attention globally, the basic needs of PwD have been reinforced (Darcy, Pegg 2011) in the recent years. "Another reason for the industry to include individuals with physical disabilities is because they are such a large market and will continue to grow as the baby - boom generation ages, lifespan increases and medical technology improves. The number of people with higher level of disabilities and age 65 or above is also moving in the same growing direction. Another market segment related to PwD is seniors with access needs. People may be disabled either temporarily or permanently through the result of ageing [...]. From the tourism industry's point of view, the market potential of the PwD group seems to be large, since about $10 \%$ of the world population possesses some type of disability" (Ieng Loi, Hang Kong 2015). Despite this important potential market, the global tourism seems to marginalize or even discourage people with disabilities from buying its products (Horner, Swarbrooke 2004).

\section{Estimated size and benefits of tourist market for people with disabilities}

According to the estimates made by the World Health Organization, 10\% of the inhabitants of the Earth, i.e. approximately 650 million people experience various forms of disability (Pagán 2012). Of this number, children constitute 200 million. However, due to imperfect system of jurisprudence and registration of disability in many countries, particularly leastdeveloped countries, it is not possible to determine the number and structure of the disabled precisely. The percentage of the disabled in particular countries ranges from several to tens of percent.

The statistics of the number and structure of people with dysfunctions all around the world are kept relatively poor because there is no uniform system of nomenclature and registration of disability (Tab. 1). 
Table 1: The estimated population of people with disabilities

\begin{tabular}{|c|c|c|c|}
\hline Location & $\begin{array}{l}\text { Estimated number of } \\
\text { people with disability } \\
\text { (in million) }\end{array}$ & $\begin{array}{l}\text { Persons with } \\
\text { disabilities } \\
\text { in the general } \\
\text { population }(\%)\end{array}$ & Source \\
\hline \multirow[t]{2}{*}{ WORLD } & 859 & - & Horgan-Jones, Ringaert, 2004 \\
\hline & 1000 & $15 \%$ & World Heath Organization, 2011 \\
\hline \multirow[t]{4}{*}{ EUROPE } & 50 (UE) & $11 \%$ & $\begin{array}{l}\text { European Commission, 1996; } \\
\text { Brown, } 1991\end{array}$ \\
\hline & 69-92 (UE) & $15-20 \%$ & Pühretmair, 2004. \\
\hline & 80 (UE) & - & European Commission, 2010 \\
\hline & $92-115$ & $20-25 \%$ & Stumbo, Pegg, 2005 \\
\hline \multirow[t]{2}{*}{ USA } & $50-80$ & $16-26 \%$ & Stumbo, Pegg, 2005 \\
\hline & 54 & $20,6 \%$ & Van Horn, 2016 \\
\hline CANADA & 2,7 (in 1991) & $15,5 \%$ & Van Horn, 2016 \\
\hline \multirow[t]{3}{*}{ AUSTRALIA } & more than 3 (in 1993 ) & $18 \%$ & Darcy, 1998 \\
\hline & 4,0 & $20 \%$ & Dwyer, Darcy, 2011 \\
\hline & 4,2 (in 2012) & $18,5 \%$ & ESCAP, 2014 \\
\hline \multirow[t]{2}{*}{ ASIA } & 400 & - & UNESCO, 2015 \\
\hline & 650 & - & ESCAP, 2014 \\
\hline
\end{tabular}

Source: own study based on literature review

From the estimated statistics presented above, there is a simple conclusion that addressing tourism market to the need of the people with disability is not only a mean to fulfill social responsibility, but the large number of people with disabilities around the world can at the same time bring economic incentive as they can generate new business opportunities for the tourism industry (Bi et al. 2007).

\section{Barriers to accessing tourism by people with disabilities}

When a person chooses to leave his or her normal environment, however temporarily, there is much more than the physical impact of displacement that is experienced. The effects of social and cultural "displacement" also become an integral part of the experience even in the inner world of the tourist.

Tourism activity in the lives of the disabled people constitutes, first of all, the form of their adaptation to normal life (Łobożewicz, Bieńczyk 2001). The conditions that must be met so that the disabled could fully take advantage of the tourist services are the proper preparation of the tourist offer and concern so that the environment they have contact with would not create barriers (Łobożewicz, Bieńczyk 2001).

The literature lists numerous classifications of the barriers imposed to the disabled people. The most popular one is classification by R. W. Smith (1987) that enumerates three groups of the barriers: intrinsic, environmental and interactive ones (Tab. 2). 
Table 2: Classification of the barriers according to R.W. Smith

\begin{tabular}{|c|c|c|}
\hline Intrinsic barriers & Environmental barriers & Interactive barriers \\
\hline $\begin{array}{l}\text { - lack of knowledge, i.e. } \\
\text { unfamiliarity with the } \\
\text { possibility of spending } \\
\text { free time, } \\
-\quad \text { health problems } \\
\text { limiting tourist } \\
\text { activity, } \\
-\quad \text { inadaptability of the } \\
\text { disabled in the sphere } \\
\text { of social } \\
\text { communication, } \\
\text { - psychophysical } \\
\text { dependence of the } \\
\text { disabled people from } \\
\text { other people. }\end{array}$ & 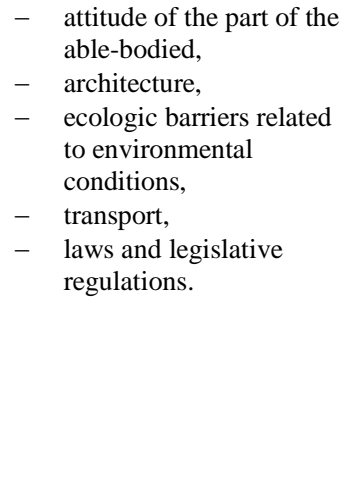 & $\begin{array}{l}\text { - lack of adjustment of } \\
\text { the abilities of the } \\
\text { disabled to the type and } \\
\text { form of activity, } \\
\text { - limited communication } \\
\text { of the disabled people. }\end{array}$ \\
\hline
\end{tabular}

Source: own study based on: SMITH, R.W. Leisure of disabled tourist. Barriers to participation. Annals of Tourism Research, 14, 1978, 376-389.

Mentioned above barriers can also present as an interplay between the inner and outer world of the tourists. Clearly it is not only environmental factors or the person's impairment that affect the experience. Attitudes, senses and feelings are intangible factors that nevertheless can have a tangible influence or a significant role in the constant interplay between the inner and outer world of the tourists (Foggin 2011) (Fig. 1).

Figure 1: The inner and outer worlds of the disabled tourists

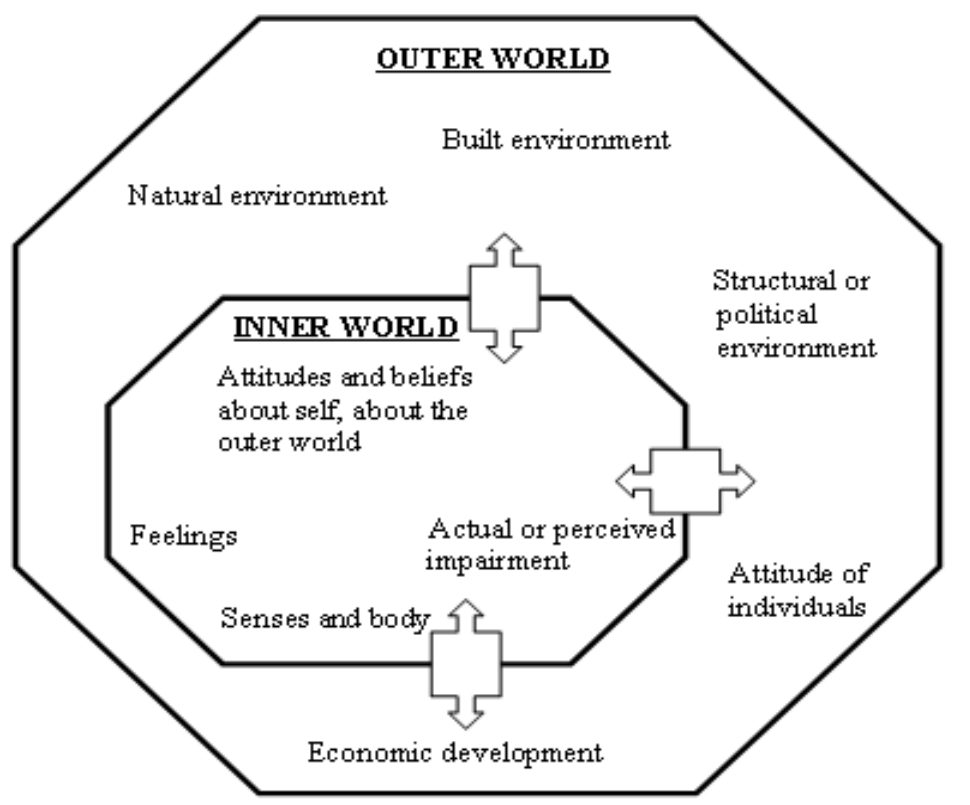

Source: FOGGIN, B. Tourism in the Leisure Lives of People with Disability. In: D. BUHALIS and S. DARCY (ed.). Accessible Tourism. Concepts and Issues. Bristol: Channel View Publications, 2011, 98-122.

Another classification is quoted by T. Łobożewicz and G. Bieńczyk (2001), who divide the barriers to practising tourism by the disabled people into:

- architectural barriers (obstacles in moving),

- economic barriers (financial),

- social barriers (attitude of the society to disability, overprotection towards the disabled and isolation of the disabled),

- lack of adjustment to the information (distorted information or its lack),

- lack of tourist equipment adjusted to the age and type of disability. 


\section{Tourism market segmentation}

The tourism sector is not uniform, therefore there is its segmentation into smaller units. The aim of the division into segments is to determine the characteristics of needs and consumption behaviors for optimization of the tourist offer and forming the value chain. In the process of segmentation of the tourism market four classes of indicators, applied separately or in a specific combination, are usually used. They help to describe a new product, services and possible customers. Due to them the statistical point of view is determined. The elements distinguished by M.E. Porter (2006) are:

- variant of the product,

- type of buyer,

- distribution,

- geographical location of the buyer.

Referring to the above-mentioned, within the tourism industry we can distinguish the market of tourism of the disabled that requires particular individualized kinds of services/products, possesses a specific type of the customer that people with dysfunctions are. Taking into consideration location and distribution it assumes the global scale, due to which by assumptions travelling can take place without barriers all over the world. When talking about the tourism market for people with disability it is very important to take a look at the pyramid of demand types and the size of market segments. With the increase of tourist's disability degree, the market of tourism products and services is decreasing. Most of tourist packages are dedicated to people with low accessibility requirements (any kind of disability), but going further to severe degree of disability, where individuals require highest level of availability, the number of offers on the travel market is significantly reduced (Fig. 2).

Figure 2: Pyramid of demand types: the continuum of abilities

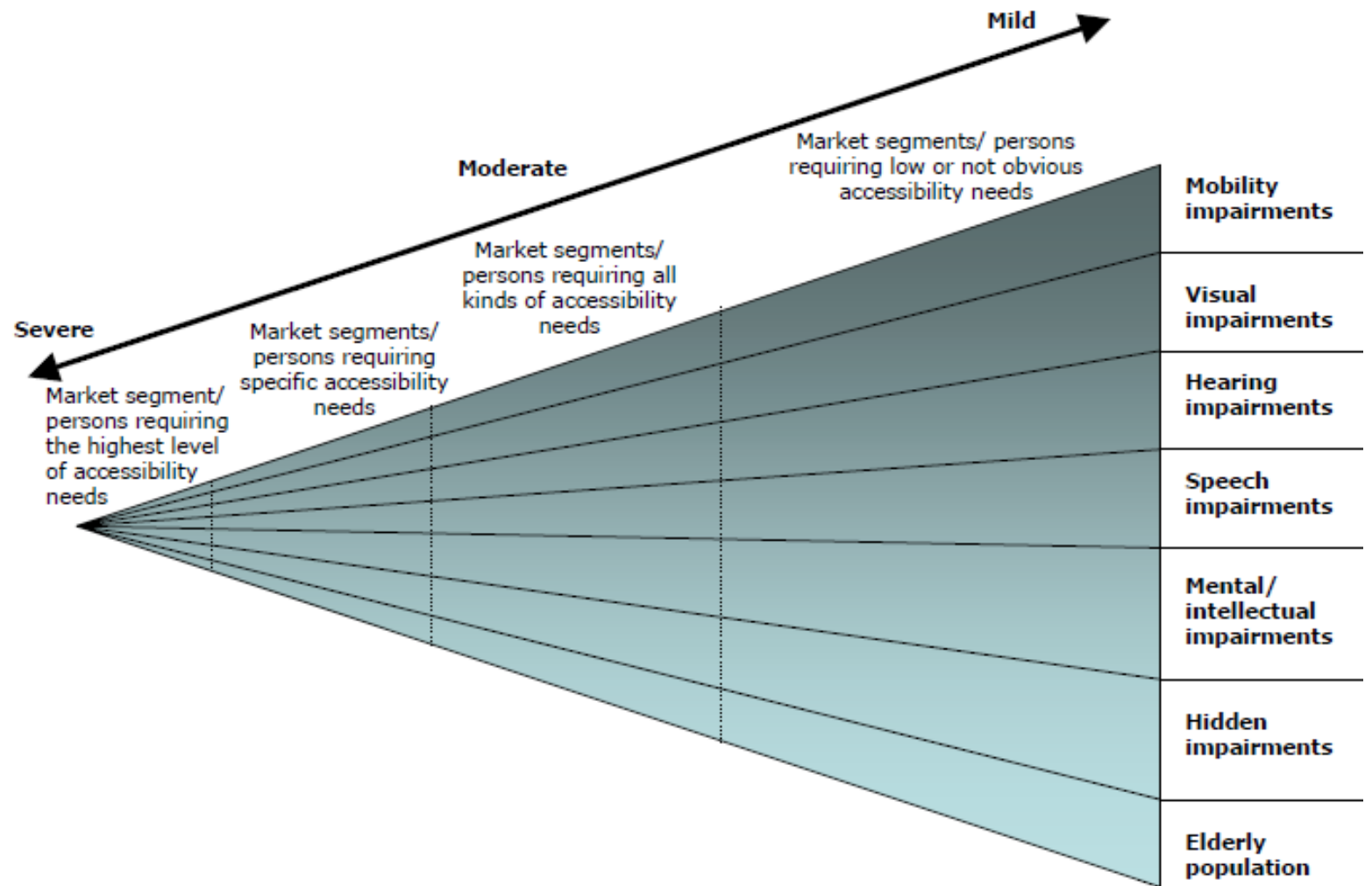

Source: BUHALIS, D. and S. DARCY (ed.). Accessible Tourism. Concepts and Issues. Bristol: Channel View Publications, 2011. 


\section{Accessibility and the tourism system}

Generally, the tourism industry is a complex system of independent providers whose aim is aim to serve the consumer. A variety of stakeholders are involved, which often has conflicting needs, wants and interests in the industry (Buhalis 2003). The entire tourism system is defined by five elements: a traveler-generating region, a destination region, a transit region, a travel and tourism industry as well as the external environment (Leiper 1995).

Figure 3 develops the framework of the tourism system developed by Leiper (1995) and Buhalis (2003) further by adding customers' information needs. These are spread alongside the system, ranging from the pre-travel stage via the actual travel phase (transit and at the destination) to the after-trip period. Throughout all travel stages, customers have particular information needs that have to be fulfilled in order to deliver tourism products in an adequate way. By focusing on tourism products and services, the expanded framework also incorporates the six "As", which are regarded as essential for analyzing tourism destinations. These are amenities, attractions, ancillary services, activities, available tourism packages and accessibility (Buhalis 2000) (Fig. 3).

Figure 3: The Tourism system and accessibility

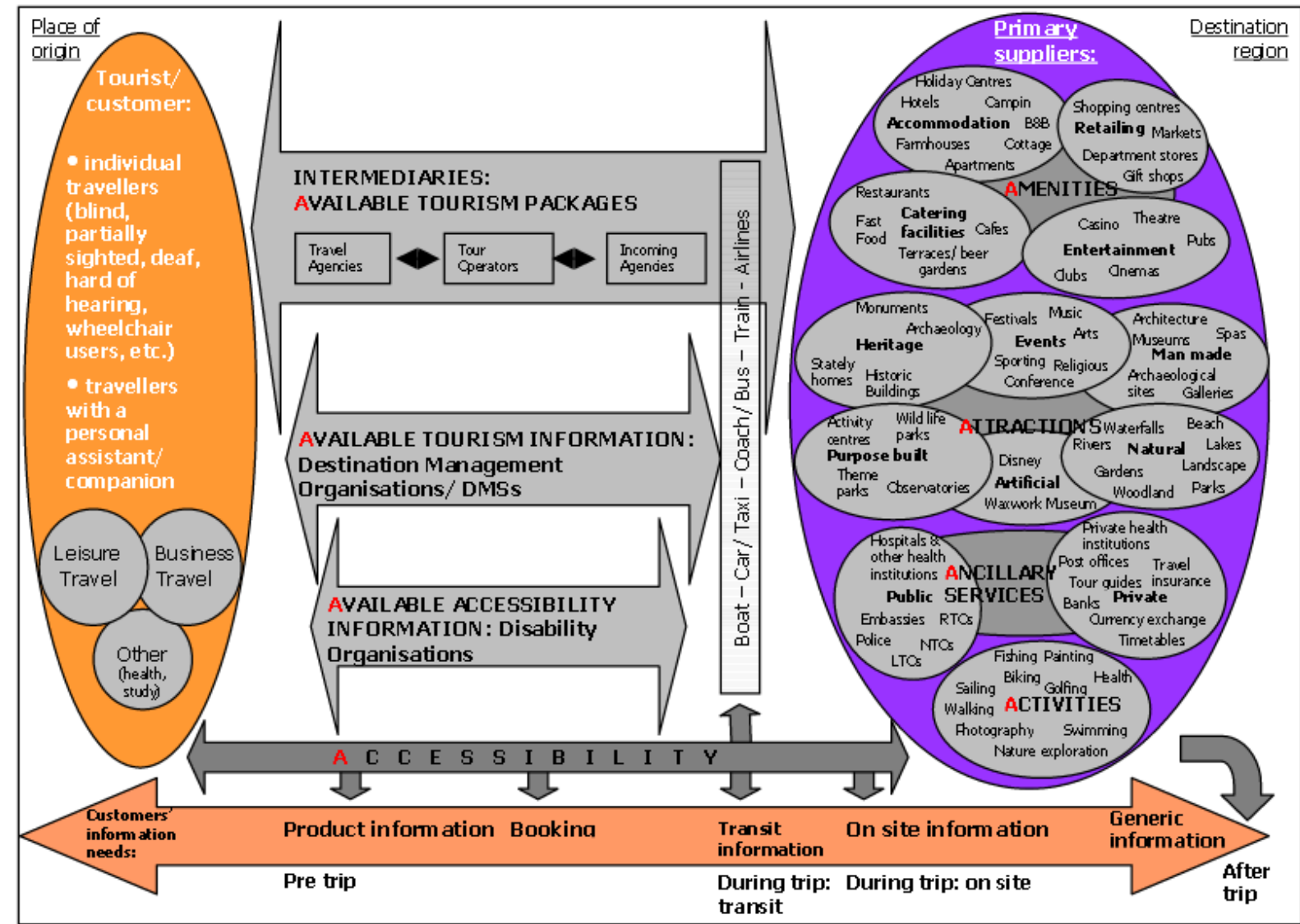

Source: BUHALIS, D., E. MICHOPOULOU, V. EICHHORN and G. MILLER. Accessibility market and stakeholder analysis, One-Stop-Shop for Accessible Tourism in Europe (OSSATE). Surrey: University of Surrey, 2005.

It is critical to support people with accessibility needs for their entire trip. What is needed is the creation of accessible paths throughout the system because isolated accessible facilities do not add to the travel and tourism experience. The collection and dissemination of comprehensive information about the entire accessible sub-system is a very difficult and 
challenging task given the amount of tourist destinations and tourism suppliers in Europe (Buhalis, Eichhorn, Michopoulou, Miller 2005).

\section{The importance of tourism in the life of people with disability}

Tourism plays an important role in the life of each person. Through touristic activity and recreation the man has the possibility of satisfying numerous needs, among other things, the need for relaxation, cognition, self-realization, improvement of the condition of physical and mental health as well as others. The needs shape motivations prompting to undertake a touristic activity. A particular hierarchy of needs is characteristic for disabled people who due to limited possibilities - pay more attention to each decision. Furthermore, the disabled constitute a group that decides for tourist trips more seldom than the rest of the society. Undertaking a touristic activity is often associated with the presence of specific needs. Abraham Maslow spread the theory of needs hierarchy according to which the needs are of hierarchical character. Human behaviour is driven by unmet needs. Their meeting should take place in a particular order. Satisfying the needs of the lower level (physiological, safety) constitutes the condition of meeting the needs of the higher level (affiliation, esteem and respect, self-actualization) (Fig.4).

Figure 4: Maslow's hierarchy of needs

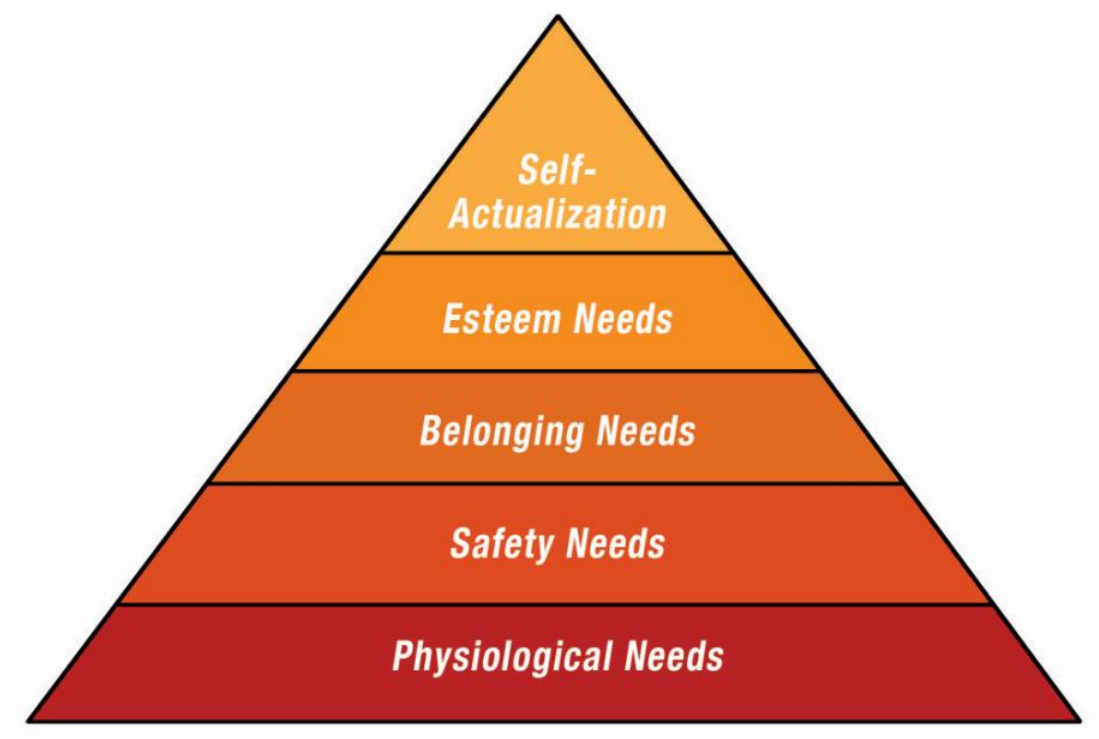

Source: own study based on www.cultbranding.com [cit. 8.February 2016]. Accessible from <http:// www.cultbranding.com>.

Pursuant to the Maslow's theory tourism may be a form of response to the basic human needs, however, it may also be a form of self-actualization in people who attribute particular values to tourism. Characteristics of the needs of the disabled people does not differ significantly from the one that is applied to the healthy people, however, disability itself undoubtedly causes reinforcement of the needs.

Theories of needs have become a basis for creating classifications of the motives of journey. Among them, it is worth drawing attention to the one proposed by Przecławski (1997) who differentiates nine groups of motives prompting to tourist trips. These are motives related to:

- desire to visit a particular country or town,

- desire to temporally leave the place of residence,

- desire to spend particular time with somebody outside the place of residence,

- desire to make new acquaintances and new friends, 
- desire to comply with stereotypes, with the norms binding in the environment where one belongs,

- meeting emotional and aesthetic needs,

- meeting creative needs,

- meeting biological needs.

All above-mentioned needs related to practising tourism pertain to the disabled people as well. However, the ones regarding health, change of environment as well as social and cognitive motives are of utmost importance. Also very important is the desire to experience positive emotions related to movement which is a key element of psychotherapy. People with disability, by practising tourism, have an opportunity to overcome their own weaknesses and also set high and ambitious targets. By becoming members of the tourism group disabled people are not hiding themselves in their homes anymore, in their social isolation. Tourism and recreation activities are providing them willingness to live because they can break out of the monotony of their daily life and they can experience new adventures. While being a part of a group the disability is no longer an obstacle. People with impairments can feel equal, which is the most important.

Tourism has a great influence on disabled people. This impact can be divided into the three main groups:

- physical - rehabilitation of the body, improving the physical condition, etc.,

- mental - self-fulfillment, overcoming difficulties, mental development, etc.,

- social - social activation, development of proper social behaviour, etc.

Furthermore Łobożewicz (2000) distinguishes the following objectives that are set to tourism of the disabled:

- therapeutic target - continuation of the program of treatment and rehabilitation by practising tourism,

- biological target - tourism accelerates treatment processes as well as it decreases the effects of aging of the body and impedes the intellectual degradation,

- anatomical and physiological target - through the touristic activity the muscle strength is increased and the joints are also rehabilitated. By influencing the basic functions of the body, the systems: the nervous system, the circulatory system and respiratory system the following take place: general improvement of the psychophysical condition as well as prevention of muscle contractures and atrophy. The impression of the partial decrease in the disability effects and increase in endurance to effort appears,

- hygienic and health target - practicing tourism allows to strengthen the body and influences the ability to control the person's health condition. Furthermore, taking into account this aspect tourism constitutes an attraction of daily physical exercises,

- educational and psychological target - sports and touristic activities develop positive features of the character shaping the models of behaviours, teach empathy as well as overcome apathy caused by disability,

- hedonistic target - tourism may give joy and satisfaction, moreover it is not boring and it fulfills similar functions as gymnastics,

- social target - by participating in tourism the disabled people have the occasion to integrate with the society, make new social contacts, exchange experiences due to engaging in the social and cultural life as well as socializing. 


\section{Promoting sustainability to gain accessible tourism}

Accessible tourism is not only about people on wheelchair, because they represent only around $1 \%$ of the overall Europe population. Already mentioned group as well as others they can benefit from accessible tourism - older people with limited mobility, families with young children, or even healthy people in many ways.

With the rapid growth of the tourism industry the demands of tourists have been evaluating. Nowadays an easy access and a diverse experience which are a fundamental criteria of tourism for all are widely expected by tourists, consumers. Access and barrier-free tourism become important issues for all tourists, but especially for three groups: disabled persons, older persons and families with young children. But nowadays tourism stakeholders still have not recognized the importance of adjusting facilities and services to the needs of these tree groups mentioned above. There are many deficiencies in the issue of accessible products in various tourism aspects. "Most hotels, transportation facilities and tourist sites are not readily accessible physically [...]. Personnel at various tourist facilities have not been trained to provide services that accommodate disabled people or older people. Equally significant, explicit government policies and strategies to promote accessible tourism are missing, and this does not help further the human rights of people with disabilities" (World Health Organization 2011).

In the future the issue of accessible tourism will become more important and each stakeholder working on the market of tourism services will need to gain greater awareness of accessibility requirements for various types of disability. According to World Health Organization (2011) "among the main constraints encountered by tourists who are disabled, the following should come to the attention of all parts of the tourism industry:

- obstacles in the transportation infrastructure and related services,

- accessibility to accommodation and related services,

- difficulties and restrictions in gaining access to tourism sites,

- lack of sensitivity or awareness of tourism service providers".

In order to achieve the accessible tourism for all by sustainable development of tourism - as it was mentioned above - the industry needs to do a lot of changes. In the act of travelling besides the travellers themselves (the demand side, or clientele), the providers of tourist services at all spatial levels also play a significant role.

\section{Conclusion}

Tourism became recognized as a fundamental right for all. Nowadays social inclusion and equity are important principles of sustainable development. People with disabilities have their special needs regarding participation in tourism and they do not travel a lot, but on the other hand they have the same motivation of travelling. That is why this still unexplored field of tourism for people with disabilities is an ongoing trend and many initiatives are taken in this direction. These actions are intended to reduce all barriers that are standing between persons with special needs and their full participation in a tourist activity. This is possible only by recognizing the need and reason for sustainable development in each of tourism dimensions. Taking tourism as a sustainable development option must be planned and managed so that its benefits could be spread as widely as possible throughout the society and also for the particular group, which are disabled persons. 
Sustainable tourism development brings various changes in the matter of accessible tourism from which many people with limited mobility as well as other part of society can benefit. It might not be realistic to expect that these facilities would change overnight. It takes time but the most important and satisfactory fact is that tourism industry (many stakeholders) become to understand the value of this niche related to handicapped people market and they understand the meaning of requirements and awareness of disabled persons in their services and products.

Due to various forms of disability many people do not take a holiday. This is a challenge for sustainable tourism development implications and to make tourism barrier-free in the early future, by making facilities more accessible and providing training to help increase awareness and sensitivity in the tourism industry or changing legislations. The best practices to give a chance for equal participations for people with disabilities in tourism by sustainable development are connected to:

- raising the awareness of this niche market,

- designing, adjusting and promoting tourism services and products to the requirement of various kinds of disabilities,

- providing both tourism and practical information about travelling relevant to disabled people,

- offering different prices at tourist facilities in order to obtain discounts for disabled people,

- providing specially designed tours, recreation or even animation programs for people with disabilities to encourage them to take a journey.

\section{References}

[1] BI, Y., J. A. CARD and S. T. COLE, 2007. Accessibility and Attitudinal Barriers Encountered by Chinese Travellers With Physical Disabilities. International Journal of Tourism Research, 9(3), 205-216, ISSN: 1522-1970.

[2] BROWN, F., 1991.Tourism for All. Tourism Management, 12(3), 258-260, ISSN: 02615177.

[3] BUHALIS, D., 2003. eTourism: Information Technology for Strategic Tourism Management. London: Pearson (Financial Times/Prentice Hall), ISBN: 9780582357402

[4] BUHALIS, D., 2000. Marketing the Competitive Destination of the Future. Tourism Management, 21(1), 97-116, ISSN: 0261-5177.

[5] BUHALIS, D. and S. DARCY (ed.), 2011. Accessible Tourism. Concepts and Issues. Bristol: Channel View Publications, ISBN: 9781845411602.

[6] BUHALIS, D., E. MICHOPOULOU, V. EICHHORN and G. MILLER, 2005. Accessibility Market and Stakeholder Analysis, One-Stop-Shop for Accessible Tourism in Europe (OSSATE). Surrey: University of Surrey. [online]. [cit. 12th February 2016]. http://www.accessibletourism.org/resources/ossate_market_analysis_public_final.pdf

[7] CROMPTON, J. L., 1979. Motivations for Pleasure Vacation. Annals of Tourism Research, 6(4), 408-424, ISSN: 0160-7383.

[8] DARCY, S., 1998. Anxiety to Access: Tourism Patterns and Experiences of New South Wales People with a Physical Disability. Sydney: Tourism New South Wales, ISBN: 07313-5500-8. 
[9] DARCY, S. and S. PEGG, 2011, Towards Strategic Intent: Perceptions of Disability Service Provision Amongst Hotel Accommodation Managers. International Journal of Hospitality Management, 30(2), 468-476, ISSN: 0278-4319.

[10] DISABILITY DISCRIMINATION ACT, 1995. [online]. [cit. 10th February 2016]. Accessible from: http://www2.le.ac.uk/offices/.../protected.../disability.../disability.pdf

[11] DWYER, L. and S. DARCY, 2011. Economic Contribution of Tourists with Disabilities: An Australia Approach and Methodology. In: D, BUHALIS, S. DARCY (ed.), Accessible Tourism. Concepts and Issues. Bristol: Channel View Publications, 214-237, ISBN: 9781845411602.

[12] ESCAP (United Nations Economic and Social Commission for Asia and the Pacific), 2014. Making the Right Real for Persons With Disabilities [online]. [cit. 10th February 2016]. Accessible from: http://www.unescap.org/sites/default/files/DisabilityFactsheet.pdf.

[13] EUROPEAN COMMISSION, 1996. Making Europe Accessible for Tourists with Disabilities: Handbook for the Tourist Industry. Luxemburg: Office for Official Publications of the European Communities, ISBN: 9789282773000.

[14] EUROPEAN COMMISSION, 2010. Communication from the Commission to the European Parliament, the Council, the European Economic and Social Committee and the Committee of the Regions. European Disability Strategy 2010-2020: A Renewed Commitment to a Barrier-Free Europe. Luxemburg: Office for Official Publications of the European Communities [online]. [cit. 12th February 2016]. Accessible from: http://eur-lex.europa.eu/LexUriServ/LexUriServ.do?uri=COM:2010:0636:FIN:en:PDF

[15] FOGGIN, B., 2011. Tourism in the Leisure Lives of People with Disability. In: D. BUHALIS, S. DARCY (ed.). Accessible Tourism. Concepts and Issues. Bristol: Channel View Publications, 98-122, ISBN: 9781845411602.

[16] HORGAN-JONES, M. and L. RINGAERT, 2004. Accessible Tourism in Manitoba. Niagara Falls: TTRA - Travel and Tourism Research Association [online]. [cit.10th February 2016]. Accessible from: http://www.ttra.com/pub/uploads/AccessibleTourismInManitoba.htm.

[17] HORNER, S. and J. SWARBROOKE, 2004. Tourism and Travellers with Disabilities. International Cases in Tourism Management, 324-337, ISBN: 9780750655149.

[18] IENG LOI, K. and W. HANG KONG, 2015. People with Disability $(P w D)$ in the Tourism Industry - Concepts and Issues [online]. [cit. 10th February 2016]. Accessible from: http://wp.nyu.edu/cts2015/wp.../sites/.../Loi-and-Kong.pdf.

[19] LEIPER, N., 1995. Tourism Management. Melbourne: RMIT Press, ISBN: 9781862505339

[20] ŁOBOŻEWICZ, T. (ed.), 2000. Turystyka i rekreacja ludzi niepetnosprawnych. Warszawa: WSE, ISBN: 83-86990-01-5.

[21]ŁOBOŻEWICZ, T. and G. BIEŃCZYK, 2001. Podstawy turystyki. Warszawa: Wyższa Szkoła Ekonomiczna, ISBN: 83-86990-12-0.

[22] PAGAN, R., 2012. Time Allocation in Tourism for People with Disabilities. Annals of Tourism Research, 39(3), 1514-1537, ISSN: 0160-7383.

[23] PORTER, M. E., 2006. Przewaga konkurencyjna: osiaganie i utrzymywanie lepszych wyników. Gliwice: Helion, ISBN: 8324601554. 
[24] PRZECŁAWSKI, K., 1997. Człowiek a turystyka. Zarys socjologii turystyki. Kraków: Wyd. Albis, ISBN: 83-906452-0-3.

[25] PUHRETMAIR, F., 2004. It's Time to Make eTourism Accessible. In :K., MIESENBERGER, J. KLAUS, W. ZAGLER, D. BURGER (ed.), Computers Helping People with Special Needs, 9th International Conference, ICCHP 2004, Paris, France, July 7-9, 2004, Proceedings. Berlin: Springer Verlag, 272-279, ISBN: 92-894-3730-8.

[26] SMITH, R.W., 1978. Leisure of Disabled Tourist. Barriers to Participation. Annals of Tourism Research, 14, 376-389, ISSN: 0160-7383.

[27] STUMBO, N.J. and S. PEGG, 2005. Travellers and Tourists with Disabilities: A Matter of Priorities and Royalties. Tourism Review International, 8(3), 195-209, ISSN: 15442721

[28] UNESCO (United Nations Educational, Scientific and Cultural Organization), 2015. Disabilities in Asia-Pacific [online]. [cit. 10th February 2016]. Accessible from: http://www.unescobkk.org/education/inclusive-education/what-is-inclusiveeducation/disabilities-in-asia-pacific.

[29] VAN HORN, L., 2016. Travellers with Disabilities: Market Size and Trends [online]. [cit. 10th February 2016]. Accessible from: http://ncpedp.org/access/isu-travel.htm.

[30] WORLD HEALTH ORGANIZATION, 2011. World Report on Disability. Geneva: World Health Organization, ISBN: 978-9241564182. 